\title{
Nutritional enrichment of broiler breast meat through dietary supplementation of Indian ginseng Withania somnifera and synbiotic substances under semi-arid climatic conditions
}

\author{
Sonal Thakur ${ }^{1}$, Tribhuwan Sharma ${ }^{1}$, Radhe Shyam Arya ${ }^{1}$, Basant Bais ${ }^{2}$ and Vijay Kumar Agrawal ${ }^{3}$
}

1. Department of Animal Nutrition, College of Veterinary and Animal Sciences, Rajasthan University of Veterinary and Animal Science, Bikaner - 334 001, Rajasthan, India; 2. Department of Livestock Production and Technology, College of Veterinary and Animal Sciences, Rajasthan University of Veterinary and Animal Science, Bikaner - 334 001, Rajasthan, India; 3. Department of Animal Genetics and Breeding, College of Veterinary and Animal Sciences, Rajasthan University of Veterinary and Animal Science, Bikaner - 334 001, Rajasthan, India.

Corresponding author: Sonal Thakur, e-mail: drsonalvet@rediffmail.com

Co-authors: TS: tribhuwan6761@yahoo.co.in, RSA: aryadrradheyshyam@gmail.com, BB: basantbais@gmail.com, VKA: drvijayvet2016@rediffmail.com

Received: 01-06-2017, Accepted: 27-09-2017, Published online: 03-11-2017

doi: 10.14202/vetworld.2017.1301-1306 How to cite this article: Thakur S, Sharma T, Arya RS, Bais B, Agrawal VK (2017) Nutritional enrichment of broiler breast meat through dietary supplementation of Indian ginseng Withania somnifera and synbiotic substances under semi-arid climatic conditions, Veterinary World, 10(11): 1301-1306.

\begin{abstract}
Aim: The present study was conducted to explore the effect of supplementation of Withania somnifera and synbiotics alone or in combination on the composition of broiler breast meat under heat stress conditions.

Materials and Methods: A 42-day feeding trial was conducted on 360 broiler chicks randomly allotted into eight treatment groups with three replicates each under completely randomized design. The $\mathrm{T}_{1}$ group was kept as control whereas $\mathrm{T}_{2}-\mathrm{T}_{4}$ were supplemented with $0.5 \%, 1 \%$, and $1.5 \% \mathrm{~W}$. somnifera root powder; $\mathrm{T}_{5}$ and $\mathrm{T}_{6}$ were supplemented with $0.025 \%$ and $0.050 \%$ synbiotic and $\mathrm{T}_{7}$ and $\mathrm{T}_{8}$ were fed on diet containing $0.25 \% \mathrm{~W}$. somnifera $+0.025 \%$ synbiotic and $0.50 \% \mathrm{~W}$. somnifera $+0.05 \%$ synbiotic, respectively. Three broilers from each replicate were sacrificed at the end of the trial to estimate crude protein (CP), ether extract and ash content of the breast muscle on dry matter basis.

Results: Significantly higher CP values and lower ether extract values were observed in $1.5 \% \mathrm{~W}$. somnifera supplemented group $\left(\mathrm{T}_{4}\right)$ or in group supplemented with $0.50 \% \mathrm{~W}$. somnifera and $0.05 \%$ synbiotic $\left(\mathrm{T}_{8}\right)$. The ash content of breast meat was observed non-significant in $\mathrm{T}_{1}-\mathrm{T}_{4}$ groups however the inclusion of synbiotics in $\mathrm{T}_{5}-\mathrm{T}_{8}$ groups significantly raised the ash contents.
\end{abstract}

Conclusion: The study concluded that inclusion of $0.5 \% \mathrm{~W}$. somnifera with $0.05 \%$ synbiotic substance enriches the total protein content and reduces the total lipids content of broiler breast meat under heat stress conditions.

Keywords: breast meat, broiler, heat stress, synbiotics, Withania somnifera.

\section{Introduction}

Poultry meat is an excellent source of high-quality protein, vitamins and minerals for human nutrition. India ranks $5^{\text {th }}$ in broiler meat production and contributes nearly $2.53 \%$ of world's chicken meat production [1]. The poultry sector contributes $1 \%$ of gross domestic product (GDP) and 11\% of livestock GDP in India. Huge economic losses often occur in broiler industries through decreased consumer acceptance, transportation and storage losses caused by deterioration in meat quality under higher ambient temperature and erratic climatic pattern. The impact of global warming has further worsened the situation. The semiarid region of Bikaner (Rajasthan) is known for its harsh, extreme climate with scanty and erratic rainfall.

Copyright: Thakur, et al. Open Access. This article is distributed under the terms of the Creative Commons Attribution 4.0 International License (http://creativecommons.org/licenses/ by/4.0/), which permits unrestricted use, distribution, and reproduction in any medium, provided you give appropriate credit to the original author(s) and the source, provide a link to the Creative Commons license, and indicate if changes were made. The Creative Commons Public Domain Dedication waiver (http:// creativecommons.org/publicdomain/zero/1.0/) applies to the data made available in this article, unless otherwise stated.
The breast muscle is well developed by genetic selection for rapid growth and carcass yield and constitute about $22-25 \%$ of the whole carcass weight [2]. The production of quality breast meat is affected by the environmental stress factors. Heat stress induces oxidative damage of tissues and this result with alteration of the chemical composition and also sensory quality of chicken meat [3]. Heat-stressed broilers produce pale, soft, and exudative breast meat with lower protein and ash content [4]. The crude protein (CP) content of breast meat decreases markedly $(p<0.05)$ with a significant increment in crude fat as the ambient temperature exceeds $33^{\circ} \mathrm{C}$ with or without high relative humidity [5]. Baziz et al. [6] reported that the heat-stressed broilers had a higher level of abdominal fat compared to broilers raised under normal temperature. Broiler such as Vencobb strain developed for faster growth and production is particularly more vulnerable to environmental stress due to their greater metabolic activity and more body heat [7].

Reduced feed intake, impaired growth performance, higher feed conversion ratio, reduced dietary digestibility, decreased plasma protein, and calcium 
levels have been reported in broilers that were subjected to chronic heat stress [8]. The quality of broiler meat is affected by temperature-associated environmental challenges as broilers are devoid of sweat glands and are fully covered with feathers [9]. The carcass quality of broiler meat reduces rapidly when the temperature humidity index (THI) exceeds the thermal comfort zone [10]. The production of quality poultry meat without any chemical residues in an economic manner is also an order of the day.

Several methods have been suggested to maintain the quality of broiler meat through alleviation of negative effects of high environmental temperature [11]. The $W$. somnifera or Indian Ginseng root powder is one such well known anabolic, hypolipidemic, antistressor, and antioxidant phytoherb [12] having homeostatic role in the body. The alkaloids found in the roots of $W$. somnifera such as withaferin and withanolides are responsible for most of its biological properties [13]. Limited information suggests that an organic growth promoter substance like synbiotics could provide additive benefits in growth performance [14] through increase digestibility and availability of proteins, vitamins, and mineral elements [15].

Thus, the present study was undertaken to observe the anabolic and hypolipidemic effect of $W$. somnifera on broiler breast meat composition and the nutrient sparing effect of synbiotics in heat-stressed broilers during the transition month of March-April under semi-arid climatic condition.

\section{Materials and Methods}

\section{Ethical approval}

An approval from the Institutional Ethical Committee was obtained before the onset of experimental trial.

\section{Procurement of experimental material}

360-day-old unsexed Vencobb broiler chicks of similar body weight and in good health condition were procured from commercial hatchery (M/s Kewalramani Hatcheries, Ajmer, Rajasthan, India). The $W$. somnifera root powder (M/s Mohanlal and Sons Pvt., Ltd., Bikaner, Rajasthan, India) and synbiotic substances (Polchem Pharma, Pune,
Maharashtra, India) in sufficient quantity were procured. The readymade broiler starter and finisher feed in mash form were procured from reputed poultry feed manufacturer (Venkys Pvt., Ltd., Ajmer, Rajasthan, India). The proximate composition of broiler starter, broiler finisher, $W$. somnifera, and synbiotic is presented in Table-1. The ingredient composition of synbiotic substance is presented in Table-2.

\section{Experimental design}

Completely randomized design was adopted in the present study. The broilers were randomly divided into eight treatment groups $\left(\mathrm{T}_{1}-\mathrm{T}_{8}\right)$ with three replicates of 15 chicks each. The $T_{1}$ group was kept as control without any supplementation whereas $\mathrm{T}_{2}, \mathrm{~T}_{3}$, and $\mathrm{T}_{4}$ were supplemented with $0.5 \%, 1 \%$, and $1.5 \% \mathrm{~W}$. somnifera root powder; $\mathrm{T}_{5}$ and $\mathrm{T}_{6}$ were supplemented with $0.025 \%$ and $0.050 \%$ synbiotic and $\mathrm{T}_{7}$ and $\mathrm{T}_{8}$ were fed on diet containing $0.25 \% \mathrm{~W}$. somnifera $+0.025 \%$ synbiotic and $0.50 \% \mathrm{~W}$. somnifera $+0.05 \%$ synbiotic, respectively.

\section{Feeding and management}

A 42-day experimental feeding trial was conducted in the experimental unit section of Poultry Farm of College of Veterinary and Animal Sciences, Bikaner, Rajasthan, under standard feeding and managemental conditions with broiler starter (0-21 days) and broiler finisher (21-42 days) ration. The chicks were vaccinated against New Castle Disease and Infectious Bursal Disease at the age of $4^{\text {th }}$ and $14^{\text {th }}$ day, respectively. All the birds were maintained in deep litter pens under natural cross ventilated conditions, and standard managemental practices were adopted throughout the trial to reduce systemic errors. The stocking space of $550 \mathrm{~cm}^{2}$ and $800 \mathrm{~cm}^{2}$ per broiler was provided at 0-4 weeks and 4-6 weeks of age, respectively. 23-h lighting schedule was maintained with free access to feed and water during the whole trial.

\section{Collection of weather information}

The weekly weather information related to ambient temperature and relative humidity was collected from the Meteorological Department, Agricultural Research Station of Swami Keshwanand Rajasthan, Agricultural University, Bikaner, Rajasthan (Table-3).

Table-1: Proximate analysis ${ }^{1}$ of broiler feed, Withania somnifera and synbiotic substances.

\begin{tabular}{|c|c|c|c|c|}
\hline Chemical composition & Broiler starter & Broiler finisher & Withania somnifera & Synbiotic mixture \\
\hline \multicolumn{5}{|c|}{ Proximate principles (\%) (dry matter basis) } \\
\hline Moisture & 7.0 & 7.0 & 4.88 & 3.96 \\
\hline Organic matter & 93.0 & 93.0 & 95.12 & 96.04 \\
\hline Crude protein & 22.87 & 20.1 & 5.97 & 23.43 \\
\hline Ether extract & 5.8 & 6.9 & 0.65 & 0.5 \\
\hline Crude fiber & 3.95 & 4.36 & 13.8 & 3.5 \\
\hline ME (kcal/kg feed) & 2900 & 3100 & - & - \\
\hline \multicolumn{5}{|l|}{ Mineral composition (\%) } \\
\hline Calcium & 1.02 & 1.06 & 1.17 & 0.83 \\
\hline Phosphorus & 0.96 & 0.81 & 0.63 & 1.28 \\
\hline
\end{tabular}

${ }^{1}$ Average of the values determined on samples compounded on three occasions 


\section{Parameters studied}

Three broilers from each replicate were sacrificed at the end of trial with minimum stress and discomfort as per standard procedure [16]. The breast meat portion was harvested after evisceration and kept under refrigerated condition at $4^{\circ} \mathrm{C}$ for $24 \mathrm{~h}$. Breast meat samples were analyzed for total CP, ether extracts and ash content as per standard Association of Official Analytical Chemists Procedure [17] and were expressed on dry weight basis.

\section{Statistical analysis}

The THI values for different weeks were calculated as per formula suggested by Kelly and Bond [18].

$\mathrm{THI}=\mathrm{Ta}-(0.55-0.55 \mathrm{XRH}) \times(\mathrm{Ta}-58.8)$

Where $\mathrm{Ta}=$ ambient temperature in Fahrenheit and $\mathrm{RH}=$ Relative humidity divided by 100 .

One-way analyses of variance were performed using the general linear model procedure of SPSS software version 20.0 to test the effect of different level of $W$. somnifera and synbiotic alone or their combination $\left(\mathrm{T}_{1}-\mathrm{T}_{8}\right)$ on breast meat quality. Means of different groups were compared using Duncan's multiple range tests.

\section{Results}

The assessment of heat stress condition on broiler during the trial was carried out and the values and trends of mean weekly temperature, relative humidity and THI are depicted in Figure-1. The mean weekly temperature was observed to be higher in all the weeks except $2^{\text {nd }}$ week with erratic nature of temperature fluctuation was observed. The broilers were exposed to gradually declining relative humidity till $4^{\text {th }}$ week that suddenly dipped in the $5^{\text {th }}$ week and again increased in the last week of study. The erratic pattern of climate change in terms of temperature and humidity particularly during the $5^{\text {th }}$ and $6^{\text {th }}$ weeks

Table-2: Active principles present in synbiotic used in the experimental trial.

\begin{tabular}{llc}
\hline Ingredients & Active constituents & Concentration \\
\hline Prebiotic & Mannan-oligosaccharide & $14-16 \%$ \\
Probiotics & Lactobacillus acidophilus & $10^{9} \mathrm{CFU} / \mathrm{g}$ \\
& Lactobacillus bulgaricus & \\
& Lactobacillus plantarum & \\
& Streptococcus faecium & \\
& Bifidobacterium bifidum \\
\hline
\end{tabular}

suggests the effect of heat stress on the body condition of broilers. However, continuous high THI value above thermal comfort zone except $2^{\text {nd }}$ week of trial indicates the high level of environmental stress during the whole trial period.

The proximate composition of broiler breast meat $($ Table-4) revealed significant $(p<0.05)$ difference in mean CP content overall the treatments. The mean CP (dry matter basis) was highest in the broiler group supplemented with $1.5 \% \mathrm{~W}$. somnifera however comparable performance was observed in $\mathrm{T}_{8}$ group

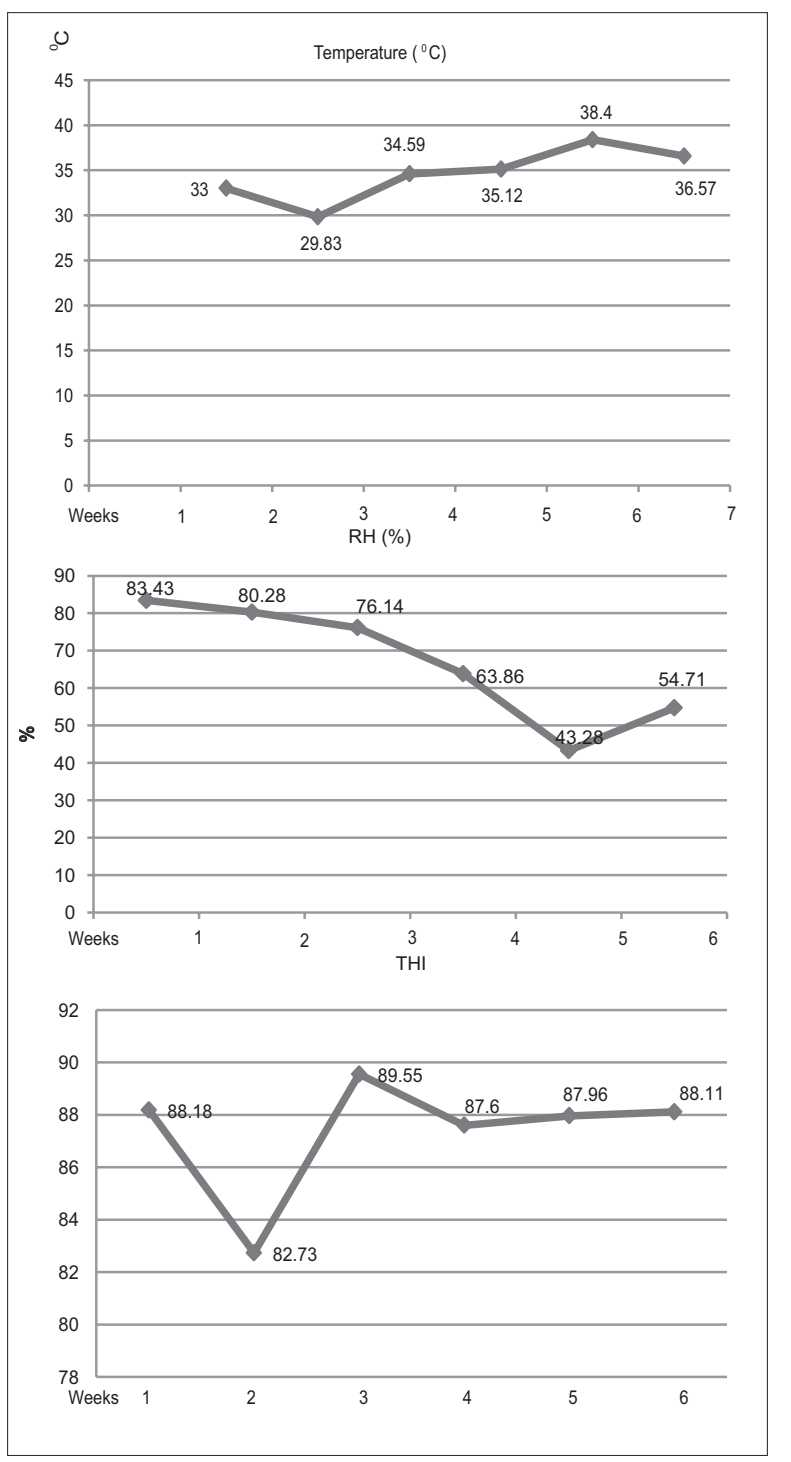

Figure-1: Temperature, relative humidity, and temperature humidity index trend over the weeks.

Table-3: Ambient temperature, relative humidity and THI observed during different weeks of experimental trial.

\begin{tabular}{|c|c|c|c|c|c|c|c|c|c|}
\hline \multirow[t]{2}{*}{ Weeks of trial } & \multicolumn{3}{|c|}{ Ambient temperature $\left({ }^{\circ} \mathrm{C}\right)$} & \multicolumn{3}{|c|}{ Relative humidity (\%) } & \multicolumn{3}{|c|}{ THI } \\
\hline & Min & Max & Avg & Min & Max & Avg & Min & Max & Avg \\
\hline Week-1 & 13.00 & 36.60 & 33.00 & 45.00 & 96.00 & 83.43 & 56.28 & 91.81 & 88.18 \\
\hline Week-2 & 12.50 & 34.60 & 29.83 & 47.00 & 87.00 & 80.28 & 55.28 & 90.42 & 82.73 \\
\hline Week-3 & 13.40 & 36.60 & 34.59 & 22.00 & 83.00 & 76.14 & 62.31 & 91.94 & 89.55 \\
\hline Week-4 & 11.00 & 39.40 & 35.12 & 13.00 & 82.00 & 63.86 & 64.07 & 90.41 & 87.60 \\
\hline Week-5 & 16.40 & 42.40 & 38.40 & 14.00 & 58.00 & 43.28 & 60.31 & 93.34 & 87.96 \\
\hline Week-6 & 18.20 & 37.40 & 36.57 & 23.00 & 67.00 & 54.71 & 63.19 & 90.18 & 88.11 \\
\hline
\end{tabular}

THI: Temperature humidity index 


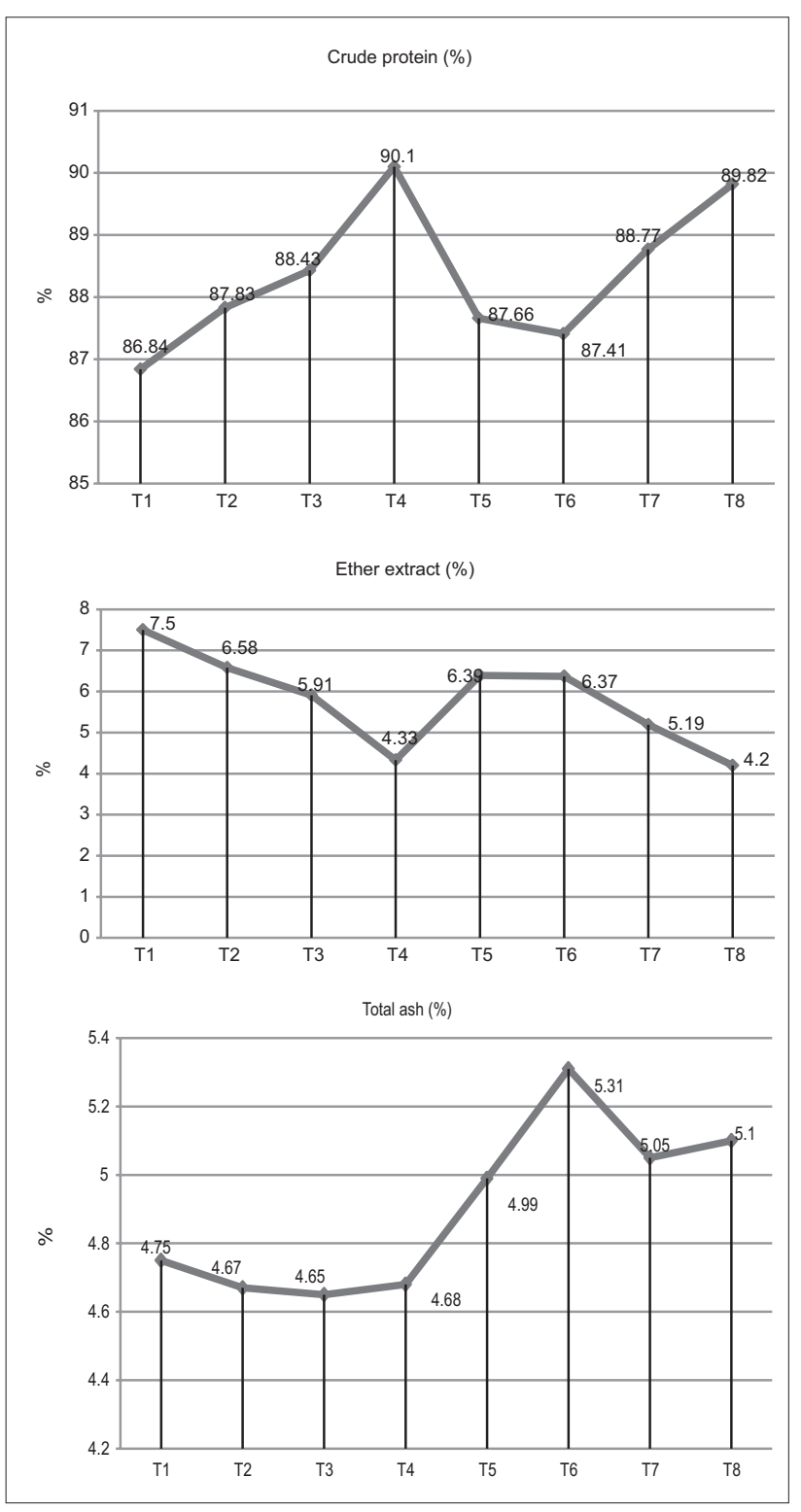

Figure-2: Trends in crude protein, ether extract and total ash content in broiler breast meat over the treatments. $\mathrm{T}_{1}$ : Control, $\mathrm{T}_{2}$ : $0.5 \%$ Withania somnifera, $\mathrm{T}_{3}: 1.0 \%$ $W$. somnifera, $\mathrm{T}_{4}: 1.5 \% \mathrm{~W}$. somnifera, $\mathrm{T}_{5}: 0.025 \%$ synbiotic, $\mathrm{T}_{6}: 0.050 \%$ synbiotic, $\mathrm{T}_{7}: 0.25 \%$ W.somnifera $+0.025 \%$ synbiotic, and $\mathrm{T}_{8}: 0.50 \% \mathrm{~W}$. somnifera $+0.05 \%$ symbiotic.

supplemented with $0.5 \% \mathrm{~W}$. somnifera $+0.05 \%$ synbiotic. The $\mathrm{CP}$ content in different treatments ranged from $86.84 \%$ to $90.10 \%$ with lowest value observed in non-supplemented broiler group $\left(\mathrm{T}_{1}\right)$. Mean ether extract of breast meat also exhibited significant $(\mathrm{p}<0.05)$ differences among the treatment groups. A downward trend in ether extract value was observed with an increased level of $W$. somnifera supplementation (Figure-2). The combined feeding approach through $W$. somnifera and synbiotic supplementation at $0.5 \%$ and $0.05 \%$ level, respectively, showed the lowest ether extract value. The results indicate the health promoting synergistic effect of herb $W$. somnifera and synbiotic substances in reduction of fatty substances. The highly significant ether extract value was observed in the control group $\left(\mathrm{T}_{1}\right)$.

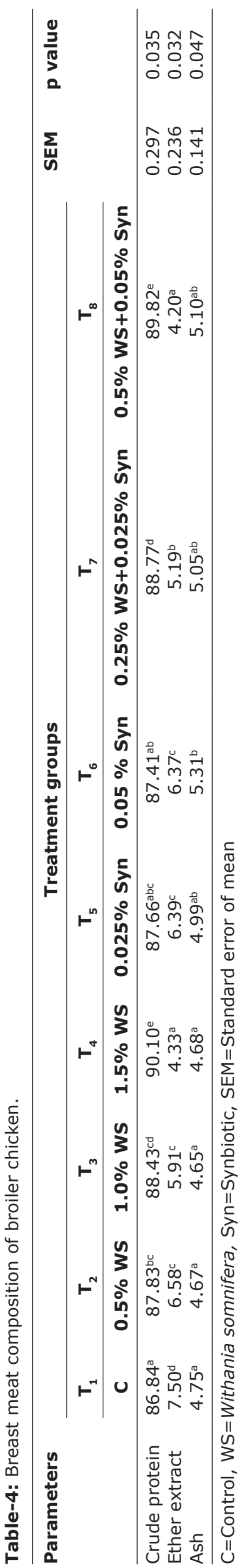

Veterinary World, EISSN: 2231-0916 
The ash content of the breast muscle was found to be highest in $0.05 \%$ synbiotic supplemented group $\left(\mathrm{T}_{6}\right)$ whereas the treatment groups $\mathrm{T}_{5}, \mathrm{~T}_{7}$, and $\mathrm{T}_{8}$ showed comparable ash content. Comparable ash content was observed in control and $W$. somnifera supplemented groups $\left(\mathrm{T}_{1}-\mathrm{T}_{4}\right)$.

\section{Discussion}

The findings pertaining to $\mathrm{CP}$ and ether extract content of the broiler breast meat revealed the gradual enrichment of protein and decline in the lipid content of the breast meat on the supplementation of $W$. somnifera root powder to broilers under heat stress conditions supports the anabolic effect of $W$. somnifera root powder as claimed in traditional Indian medicine [19]. The inclusion of synbiotic with $W$. somnifera root powder in a basal diet of broilers in treatment group $\mathrm{T}_{8}$ improved the protein content of the breast muscle which could be due to enhanced absorption of amino acids in the gut [20]. The broilers in the non-supplemented group $\left(T_{1}\right)$ showed lowest $C P$ content in breast meat through decreased protein synthesis [3] under state of high ambient temperature. Depression in chemical composition of meat in terms of low protein and higher fat observed in breast meat of broilers in control group $\left(\mathrm{T}_{1}\right)$ is in line with the findings of Akit et al. [21] who also observed $8 \%$ reduction in breast meat protein when the broilers were exposed to $34^{\circ} \mathrm{C}$ after 3 weeks of age. The higher ash values observed in the synbiotic supplemented groups might have occurred due to contributory effect of synbiotic. The difference in the ultimate nutritive quality of broiler meat depends on the supplementation of herbs and the severity of the thermal stress [22]. Similar investigation on Berberis lycium herb proved the hypolipidemic effect of herbal supplementation in boilers [23]. Likewise, Vencobb broilers raised on $1 \% W$. somnifera root powder in basal diet exhibited anabolic effect in terms of improved body weight [24].

\section{Conclusion}

The present study concluded that inclusion of $W$. somnifera root powder in the ration of broilers significantly increased the CP content and lowered the ether extract content of the breast meat. The broilers under the W. somnifera supplemented groups $\left(\mathrm{T}_{2}-\mathrm{T}_{4}\right.$, $\mathrm{T}_{7}$, and $\mathrm{T}_{8}$ ) significantly showed the enhanced performance in terms of $\mathrm{CP}$ and fat content in breast meat than control group. The results indicate the production of protein rich low fat containing broiler breast meat suitable for the health of human consumers. Thus, the anabolic and hypolipidemic effect of $W$. somnifera root powder could be used for the production of designer broiler meat with low fat and high protein that may fetch more prices to producers.

\section{Authors' Contributions}

ST carried out the study. TS planned, designed and supervised the experiment, RA and BB provided technical support, VKA carried out statistical analysis. All authors read and approved the manuscript.

\section{Acknowledgments}

The authors are thankful to the Dean, College of Veterinary and Animal Sciences, Bikaner, Rajasthan, India, for providing funds and necessary infrastructure (VCB/AND/2015/715 Dated-23/02/2016) during the course of study.

\section{Competing Interests}

The authors declare that they have no competing interests.

\section{References}

1. FAO. (2010) Poultry Meat and Eggs. In: Agribusiness Handbook. Director of Investment Centre Division, Food and Agriculture Organization of the United Nations, Rome, Italy. p77.

2. Wang, R.R., Pan, X.J. and Peng, Z.Q. (2009) Effects of heat exposure on muscle oxidation and protein functionalities of pectorals majors in broilers. Poult. Sci., 88(5): 1078-1084.

3. Lin, H., Decuypere, E. and Buyse, J. (2006) Acute heat stress induces oxidative stress in broiler chickens. Comp. Biochem. Physiol., 144: 11-17.

4. Bianchi, M., Fletcher, D.L. and Smith, D.P. (2005) Physical and functional properties of whole and ground pale broiler breast meat. Poult. Sci., 84: 803-808.

5. Gu, X.H., Li, S.S. and Lin, H. (2008) Effects of hot environment and dietary protein level on growth performance and meat quality of broiler chickens. Asian Aust. J. Anim. Sci., 21(11): 1616-1623.

6. Baziz, H.A., Geraert, P.A., Padilha, J.C.F. and Guillaumin, S. (1996) Chronic heat exposure enhances fat deposition and modifies muscle and fat partition in broiler carcass. Poult. Sci., 75: 505-513.

7. Deeb, N. and Cahaner, A. (2002) Genotype-by-environment interaction with broiler genotypes differing in growth rate, growth rate and water consumption of broiler progeny from weight-selected versus non selected parents under normal and high ambient temperatures. Poult. Sci., 81: 293-301.

8. Sohail, M.U., Hume, M.E., Byrd, J.A., Nisbet, D.J., Ijaz, A., Sohail, A., Shabbir, M.Z. and Rehman, H. (2012) Effect of supplementation of prebiotic manna oligosaccharides and probiotic mixture on growth performance of broilers subjected to chronic heat stress. Poult. Sci., 91: 2235-2240.

9. Teusan, V., Radu-Rusu, R.M. and Teusan, A. (2009) Investigations on the histological structure of the superficial pectoral muscle in cobb-500 commercial meat-type hybrid hen. Cercetari Agronom., 4(140): 39.

10. Borges, S.A., da Silva, A.V.F., Maiorka, A., Hooge, D.M. and Cummings, K.R. (2004) Effects of diet and cyclic daily heat stress on electrolyte, nitrogen and water intake, excretion and retention by colostomized male broiler chickens. Int. J. Poult. Sci., 3(5): 313-321.

11. Ogunwole, O.A., Oikeh, I., Olowe, T.O., Omotoso, R.R. and Oso, Y.A.A. (2012) Blood profile of broiler starter chickens as affected by diets supplemented with graded levels of ascorbic acid. Proceedings 17 $7^{\text {th }}$ Annual Conference Animal Science Association of Nigeria. International Conference Centre, Abuja. p203-206.

12. Varma, N., Mandeep, K., Kuldeep, K. and Jyoti, S. (2012) Comparative study of L-asparaginase from different cytotypes of Withania somnifera (L.) dunal and its purification. J. Nat. Prod. Plant. Resour., 2: 475-481.

13. Pal, A., Naika, M., Khanum, F. and Bawa, A.S. (2012) In vitro studies on the antioxidant assay profiling of root of Withania somnifera L. (ashwagandha) Dunal. Agric. Conspec. Sci., 77: 95-101. 
14. Abdel-Fattah, F.A.I. and Fararh, K.M. (2009) Effect of dietary supplementation of probiotic, prebiotic and synbiotic on performance, carcass characteristics, blood picture and some biochemical parameters in broiler chickens. Benha Vet. Med. J., 20: 9-23.

15. Ai, Q., Xu, H., Mai, K., Xu, W., Wang, J. and Zhang, W. (2011) Effects of dietary supplementation of Bacillus subtilis and fructooligosaccharide on growth performance, survival, non-specific immune response and disease resistance of juvenile large yellow croaker, Larimichthys crocea. $J$. Aquaculture., 317: 155-161.

16. Panda, P.C. (1995) Slaughtering techniques. In: Textbook on Egg and Poultry Technology. Vikas Publications, New Delhi, India.

17. AOAC. (2005) Meat and meat products. Official Methods of Analysis. $18^{\text {th }}$ ed., Vol. 2. Association of Official Analytical Chemistry, Washington, DC. p931-948.

18. Kelly, C.F. and Bond, T.E. (1971) Bioclimatic factors and their measurements. In: National Academy of Sciences: A Guide to Environmental Research on Animals. NAS, Washington, DC, USA. p71-92.

19. Rindhe, S., Suryavanshi, S.U., Khose, K.K., Ravikant, K., Adarsh, and Reothia, K. (2016) Effect of supplementation of herbal antistressor product and synthetic vitamin $\mathrm{C}$ on performance of broiler birds under physiological heat stress. World J. Pharm. Sci., 4(1): 54-59.

20. Thorat, S.G., Panwar, V.S., Dahiya, D.S. and Tewatia, B.S. (2015) Efficacy of probiotics, prebiotics and enzymes as growth promoters on the performance of broiler chicken. Haryana Vet., 54(1): 75-78.

21. Akit, M., Yalcin, S., Ozkan, S., Metin, K. and Ozdemin, D. (2005) Effects of temperature during rearing and crating on stress parameters and meat quality of broilers. Poult. Sci., 85: $1867-1874$.

22. Debut, M., Berri, C., Baeza, E., Sellier, N., Arnould, C., Guemene, D., Jehl, N., Boutten, B., Jego, Y., Beaumont, C. and Le Bihan-Duval, E. (2003) Variations of chicken technological meat quality in relation to genotype and preslaughter stress conditions. Poult. Sci., 82: 1829-1834.

23. Chand, N., Durrani, F.R., Qureshi, M.S. and Durrani, Z. (2007) Role of Berberis lyceum in reducing serum cholesterol in broilers. Asian Aust. J. Anim. Sci., 20(4): 563-568.

24. Vasanthakumar, P., Pangayarselvi, B., Sasikumar, P., Chandrasekaran,D.,Doraisamy, K. andPurushothaman,M.R. (2015) Performance of broilers fed ashwagandha (Withania somnifera) incorporated diets during summer season for alleviating heat stress. Ind. J. Anim. Res., 2646: 1-3. 